\title{
DE TRADITIONELE PRODUKTIETHEORIE EN HAAR BETEKENIS VOOR DE BEDRIJFSECONOOM
}

\author{
door Drs. H. J. Nabbe
}

\section{INLEIDING}

De traditionele produktietheorie is een bekend leerstuk uit de algemene economie. Het behandelt het vraagstuk hoe in een bedrijfshuishouding de voor de voortbrenging van een produkt benodigde hoeveelheden produktiefaktoren optimaal worden samengevoegd. Naast andere vooraanstaande economisten hebben Erich Schneider, Paul Samuelson en in het bijzonder Ragnar Frisch deze problematiek vrij uitvoerig behandeld. ${ }^{1}$ )

Het zal geen verwondering wekken dat ook de bedrijfseconomen veel interesse hebben getoond voor de traditionele produktietheorie en hebben gepoogd deze te toetsen op haar bruikbaarheid als verklarend en normatief instrument voor de bedrijfshuishouding. Wij denken dan in het bijzonder aan Erich Gutenberg, Gert Lassman en Van der Schroeff. ${ }^{2}$ )

In Nederland hebben vooral de publicaties van Van der Schroeff bekendheid verworven. Waarschijnlijk onder zijn invloed is men in Nederland de problematiek zoals behandeld door de traditionele produktietheorie gaan betitelen als het vraagstuk van de kwantitatieve verhoudingen in de produktie. ${ }^{3}$ )

Dit artikel is opgebouwd uit drie delen.

Deel 1 geeft een kort exposé van de traditionele produktietheorie.

Deel 2 analyseert de opvattingen van Van der Schroeff, Gutenberg en Lassmann over de betekenis van de traditionele produktietheorie voor de bedrijfseconomie.

Van der Schroeff wijst op enige irrealistische uitgangspunten van de traditionele theorie maar is desondanks van mening dat de theorie een denkpatroon verschaft dat bij uitstek geschikt is voor het inzicht in het vraagstuk van de kwantitatieve verhoudingen in de produktie.

Gutenberg is de opvatting toegedaan dat de produktiefunctie met variabele faktorverhoudingen niet geldt voor industriële produktieprocessen. Hij verwerpt dan ook de traditionele produktietheorie.

Lassmann heeft onderzocht of het instrumentarium van de traditionele theorie geschikt is als instrument voor produktie- en kostenplanning. Hij

1) Schneider, E. - Theorie der Produktion (Wien, 1934) - Einführung in die Wirtschaftstheorie, Teil 2 (Tübingen, 1949)

Samuelson, P. A. - Economics (New York, 1964)

Frisch, R. - The principle of substitution: an example of its application in the chocolate industry (September, 1935) - Theory of Production (Dordrecht, 1965)

${ }^{2}$ ) Gutenberg, E. - Grundlagen der Betriebswirtschaftslehre, Erster Band: Die Produktion (Berlin, 1965)

Lassmann, G. - Die Produktionsfunktion und ihre Bedeutung für betriebswirtschaftliche Kostentheorie (Köln, 1958)

Van der Schroeff, H. J. - Kwantitatieve Verhoudingen, Kosten en Economische Proportionaliteit (Amsterdam, 1967)

3) $\mathrm{Zijn}$ dissertatie over dit onderwerp was getiteld: Kwantitatieve Verhoudingen en Kosten (Amsterdam, 1940) 
heeft zich vooral verdienstelijk gemaakt door een vrij diepgaande analyse van de produktiefunctie te maken.

Lassmann erkent het bestaan van de produktiefunctie met variabele faktorverhoudingen maar acht haar niet geschikt als instrument voor de produktiepolitiek. Voor produktieplanning op korte termijn beveelt hij de produktiefunctie met vaste faktorverhouding aan en is hij voorstander van toepassing van lineaire programmering.

Aangezien het ons voorkomt dat niet alle opvattingen van genoemde bedrijfseconomen genuanceerd genoeg zijn, pogen wij enige critische kanttekeningen te plaatsen.

Zo hebben wij bezwaren tegen de naar onze mening overdreven voorstelling van Van der Schroeff dat de traditionele theorie zo'n uitstekend denkpatroon zou verschaffen voor het inzicht in het vraagstuk van de kwantitatieve verhoudingen in de produktie. De stelling van Gutenberg dat de produktiefunctie met variabele faktorverhoudingen niet zou kunnen voorkomen in de industrie blijkt niet gehandhaafd te kunnen worden.

Met betrekking tot de opvattingen van Lassmann krijgen wij de indruk dat deze in zijn ijver om lineaire programmering aan te bevelen te haastig het gehele instrumentarium van de traditionele theorie als niet realistisch terzijde heeft geschoven.

Deel 3 gaat nader in op het toepassingsgebied van de produktiefunctie en geeft een nadere beschrijving van de inhoud van deze functie.

Tenslotte wordt toegelicht hoe kwantitatieve substitutie zich zou kunnen voltrekken met betrekking tot een machinale deelactiviteit.

\section{TRADITIONELE PRODUKTIETHEORIE}

\section{Produktiefunktie}

Het produktieproces wordt opgevat als een kombinatieproces van hoeveelheden produktiefaktoren. De funktionele betrekkingen tussen de hoeveelheden produktiefaktoren enerzijds en de hoeveelheid produkt anderzijds worden beschreven door middel van de produktiefunktie. Aangezien met de produktiefunktie een zuivere kwantitatieve relatie wordt beoogd moeten zowel produkt als produktiefaktoren van konstante kwaliteit zijn.

De produktiefunktie kan in algemene termen als volgt worden geschreven: $x=f\left(a_{1} \ldots a_{n}\right)$

$$
\begin{aligned}
x & =\text { hoeveelheid produkt } \\
a_{1} \ldots a_{n} & =\text { hoeveelheden van de produktiefaktoren } A_{1} \ldots A_{n}
\end{aligned}
$$

Onderscheiden worden produktieprocessen waarvoor geldt dat een produkt in een zekere omvang slechts door één kombinatie van hoeveelheden produktiefaktoren kan worden gerealiseerd (bij gegeven $\mathrm{x}$ is $\mathrm{a}_{1} ; \mathrm{a}_{2} \ldots \mathrm{a}_{\mathrm{n}}=$ konstant), en produktieprocessen waarvoor meerdere kombinaties mogelijk zijn (bij gegeven $x$ is $a_{1} ; a_{2} \ldots a_{n}=$ variabel).

De traditionele produktietheorie interesseert zich vooral voor laatstge- 
noemde processen omdat zich met betrekking tot deze processen het ekonomisch vraagstuk stelt van de keuze uit de kwantitatieve verhoudingen der produktiefaktoren.

Onze verdere aandacht zal dan ook gericht zijn op dit soort processen welke zich laten beschrijven door een produktiefunktie met voor een gegeven $\mathrm{x}$ variabele faktorverhoudingen. ${ }^{4}$ )

\section{Isoquant}

Voor de explicatie van hun theorie bedienen de exponenten van de traditionele produktietheorie zich van een produktiefunktie met twee samenwerkende produktiefaktoren $A_{1}$ en $A_{2}$, waarvan de hoeveelheden hierna worden aangeduid met $\mathrm{a}_{1}$ en $\mathrm{a}_{2}$.

De diverse kombinaties van $a_{1}$ en $a_{2}$ die voor de produktie van een produkt in een bepaalde omvang kunnen worden aangewend en die beschreven staan in de desbetreffende produktiefunktie worden grafisch uitgebeeld op een curve.

Deze curve wordt isoquant of iso-produktcurve genoemd. De isoquant kan worden gedefinieerd als de meetkundige plaats van de punten die de kombinaties van de hoeveelheden ${ }^{5}$ ) van twee produktiefaktoren aangeven welke tot een zelfde hoeveelheid produkt leiden.

In grafiek 1 is een isoquant getekend.

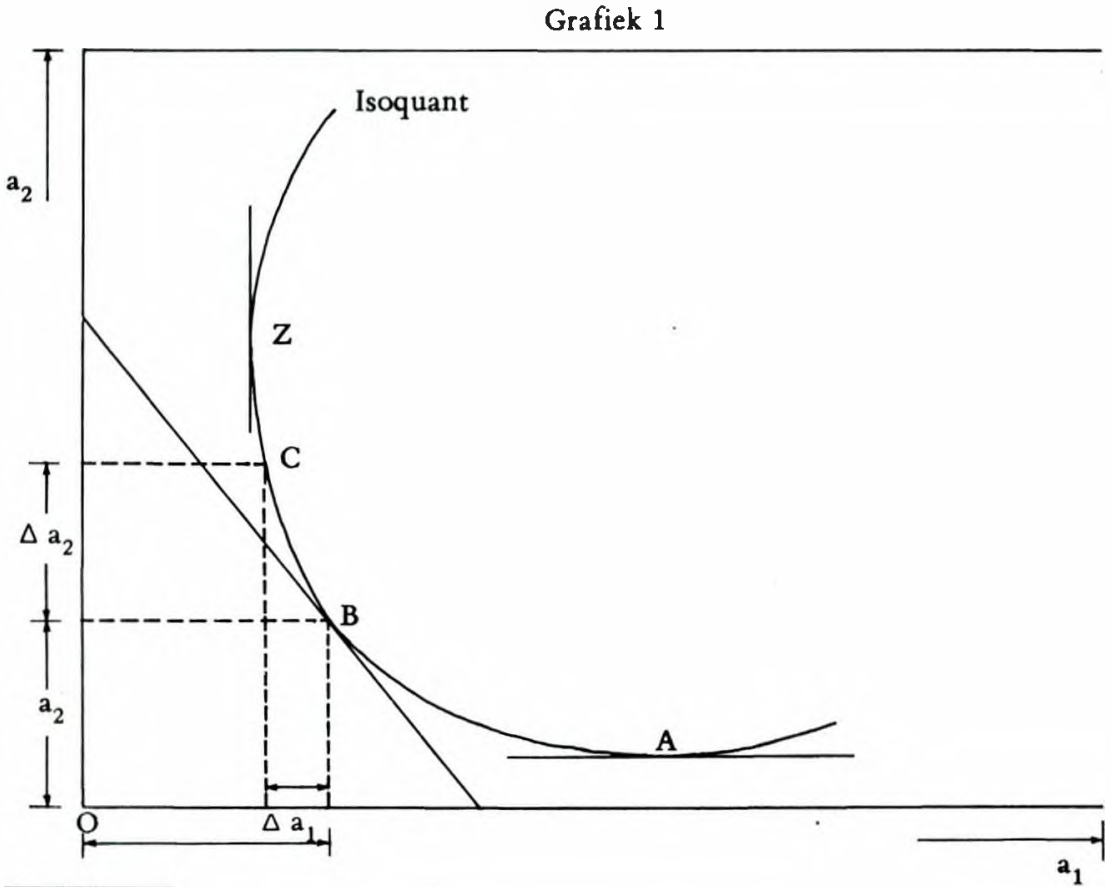

4) Voor een ander soort produktieproces geldt een produktiefunktie met voor een gegeven $x$ vaste faktorverhoudingen

5) De diverse kombinaties van de hoeveelheden produktiefaktoren worden voortaan aangeduid met de term faktorkombinaties. 
In de traditionele produktietheorie heeft de isoquant een kontinu verloop om toepassing van de differentiaalrekening mogelijk te maken. Dit betekent dus in feite dat de hoeveelheden produktiefaktoren kontinu veranderlijk zijn en dat de produktiefunktie derhalve een kontinue funktie is.

In plaats van de faktorkombinatie $\left(a_{1}: a_{2}\right)$ voorgesteld door het punt $B$ op de isoquant kan men dezelfde produktie-omvang ook realiseren door de hoeveelheid van $a_{1}$ te verminderen met $\Delta a_{1}$, en de hoeveelheid van $a_{2}$ te vergroten met $\Delta \mathrm{a}_{2}$.

Men kan aldus de faktorkombinatie $\left(a_{1} ; a_{2}\right)$ in punt $B$ vervangen door de faktorkombinatie $\left(a_{1}-\Delta a_{1} ; a_{2}+\Delta a_{2}\right)$ in punt $C$.

Soortgelijke mogelijkheden treft men aan op alle punten van de isoquant tussen $A$ en $Z$. Daarbuiten zijn de kombinaties van $a_{1}$ en $a_{2}$ irrationeel omdat er uit hoofde van het streven naar zo gering mogelijke opofferingen van hoeveelheden produktiefaktoren steeds betere kombinaties tussen $A$ en $Z$ gevonden kunnen worden.

\section{Kwantitatieve substitutie, marginale substitutieverhouding en marginaal produkt}

Men kan ook stellen dat er zich tussen $A$ en $Z$ wèl en daarbuiten géén mogelijkheden van kwantitatieve substitutie voordoen.

Onder kwantitatieve substitutie ${ }^{6}$ ) van twee produktiefaktoren dient te worden verstaan de vervanging van een hoeveelheid van de ene faktor door een hoeveelheid van de andere faktor zonder dat het produktieniveau wordt gewijzigd.

De mate waarin zich op de isoquant (kwantitatieve) substitutie voltrekt wordt aangegeven door de marginale substitutieverhouding, dit is de quotiënt

$$
\left|\begin{array}{c}
\Delta a_{1} \\
\Delta a_{2}
\end{array}\right|
$$

Voor zeer kleine veranderingen in de hoeveelheden $a_{1}$ en $a_{2}$ is de marginale substitutieverhouding $\left|\begin{array}{c}\mathrm{da}_{1} \\ \mathrm{da}_{2}\end{array}\right|$ gelijk aan de tangens van de hoek die de raaklijn in een punt van de isoquant makk met de ordinaat.

In de traditionele produktietheorie wordt de marginale substitutieverhouding uitgewerkt in termen van marginale produktverhoudingen.

Onder het marginaal produkt van een produktiefaktor wordt verstaan de verhouding tussen enerzijds de verandering in de produktie-omvang die optreedt wanneer de hoeveelheid van de produktiefaktor wordt gewijzigd bij konstant blijvende hoeveelheden van alle overige produktiefaktoren en anderzijds de verandering in de hoeveelheid van de produktiefaktor.

Het marginaal produkt van produktiefaktor $A$, aangeduid met $\lambda$, is derhal-

6) Men spreekt van kwantitatieve substitutie ter onderscheiding van een andere soort substitutie waarbij een van de samenwerkende faktoren wordt vervangen door een kwalitatief verschillende produktiefaktor (dit is kwalitatieve substitutie).

$m a b$ blz. 416 
ve $\frac{\Delta \mathrm{x}}{\Delta}$, waarbij $\Delta \mathrm{x}$ de wijziging in de produktie-omvang aangeeft.

$\Delta \mathrm{a}$

Voor zeer kleine veranderingen van a, is $\lambda=\frac{\mathrm{da}}{\mathrm{da}}$

Indien $\mathrm{a}_{1}$ wordt verminderd met $\mathrm{d}_{\mathrm{a}_{1}}$ dan daalt de produktie-omvang als volgt: $\mathrm{dx}=\lambda_{1} \mathrm{~d} \mathrm{a}_{1}$

Indien $\mathrm{a}_{2}$ wordt verhoogd met $\mathrm{d}_{2}$ dan stijgt de produktie-omvang als volgt: $\mathrm{dx}=\lambda_{2} \mathrm{~d} \mathrm{a}_{2}$

Indien de produktiedaling wordt gekompenseerd door de produktiestijging dan geldt:

$$
\left|\frac{\mathrm{da}_{1}}{\mathrm{da}_{2}}\right|=\frac{\lambda_{2}}{\lambda_{1}} \quad \text { (formule 1) }
$$

Aangezien de produktie-omvang op de isoquant ongewijzigd blijft is formule 1 relevant voor alle punten op de isoquant. In een later stadium wordt nog van deze formule gebruik gemaakt.

\section{Substitutiegebied}

In grafiek 1 is een isoquant uitgebeeld welke in relatie staat tot een bepaalde produktieomvang.

Men kan voor de verschillende hoeveelheden produkt een reeks van isoquanten tekenen die bij stijgende produktie-omvang steeds hoger in de grafische voorstelling moeten worden gesitueerd.

Grafiek 2

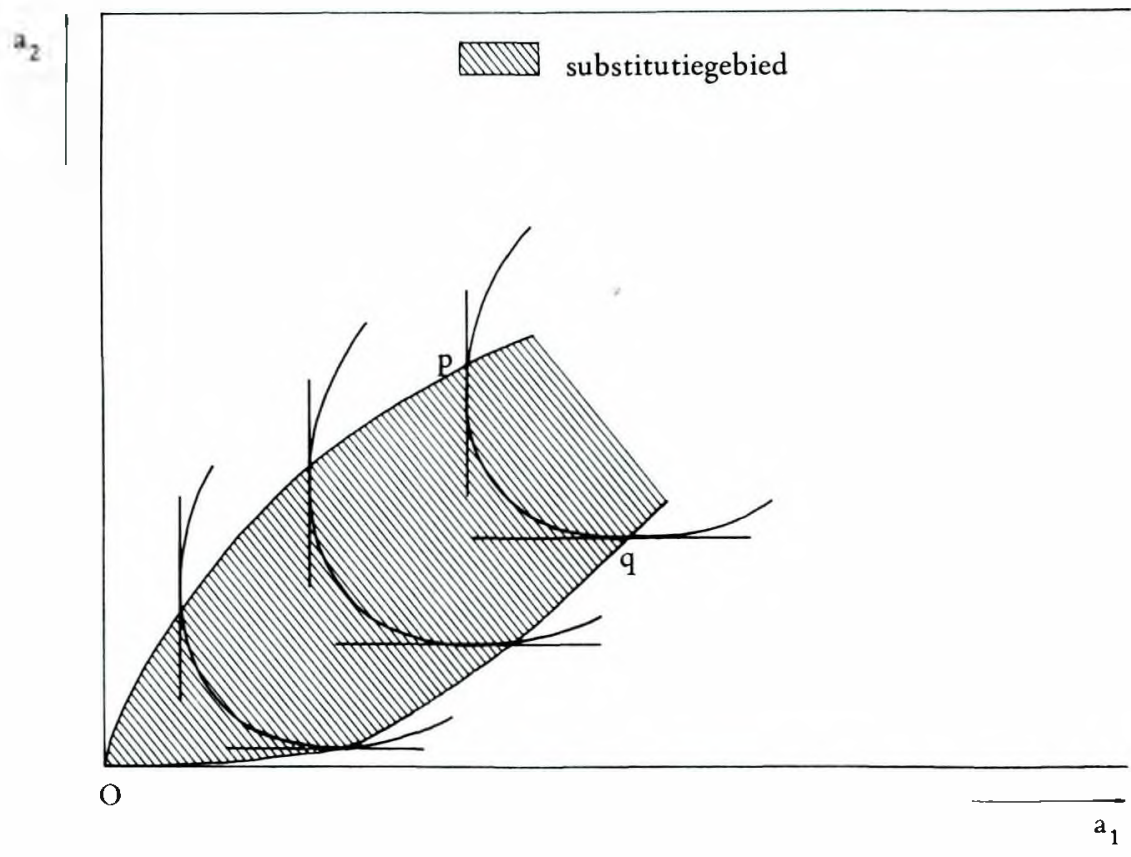


Het gebied binnen de kromme POQ wordt wel aangeduid als het substitutiegebied. Het is in dit gebied dat we voor elke produktie-omvang de optimale faktorkombinatie moeten zoeken. Aangenomen wordt dat de isoquanten elkaar in het substitutiegebied niet zullen snijden of raken. Bij volkomen deelbaarheid van de hoeveelheden produktiefaktoren is het immers ondenkbaar dat een zekere produktie-omvang verwezenlijkt zou kunnen worden door hoeveelheden $a_{1}$ en $a_{2}$ die gelijk zijn aan of kleiner zijn dan de hoeveelheden benodigd voor een lagere produktie-omvang.

\section{Optimale faktorkombinatie bij gegeven prijzen van produktiefaktoren}

De traditionele produktietheorie gaat uit van het standpunt dat voor de realisatie van een bepaalde produktie-omvang dié faktorkombinatie optimaal is welke leidt tot de laagste produktiekosten.

Gebruik makend van grafiek 1 kan gesteld worden dat de faktorkombinatie $\left(a_{1}-\mathrm{da}_{1} ; \mathrm{a}_{2}+\mathrm{da}_{2}\right)$ voorgesteld door het punt $\mathrm{C}$ te verkiezen is boven de faktorkombinatie $\left(a_{1} ; a_{2}\right)$ voorgesteld door het punt $B$ indien de kostendaling als gevolg van de vermindering van $\mathrm{a}_{1}$ met $\mathrm{da}_{1}$ groter is dan de kostenstijging als gevolg van de toeneming van $a_{2}$ met da $a_{2}$.

Dit betekent derhalve dat bij gegeven ${ }^{7}$ ) eenheidsprijzen van de hoeveelheden produktiefaktoren ( $p r i j s a_{1}=p_{1} ;$ prijs $a_{2}=p_{2}$ ) substitutie van $a_{1}$ door $a_{2}$ lonend is indien $\left|\mathrm{p}_{1}, \mathrm{da}_{1}\right|>\mathrm{p}_{2} . \mathrm{da}_{2}$ of anders gezegd indien $\left|\begin{array}{c}\mathrm{da} \\ \mathrm{da}_{2}\end{array}\right|>\frac{\mathrm{p}_{2}}{\mathrm{p}_{1}}$ In de traditionele produktietheorie wordt aangenomen dat de isoquanten in het substitutiegebied zodanig verlopen dat de marginale substitutieverhouding vanaf het punt $A$ tot het punt $Z$ steeds afneemt. Dit heeft tot gevolg dat bij voortgezette substitutie een punt wordt bereikt waarbij $\left|\begin{array}{c}\mathrm{da}_{1} \\ \mathrm{da}_{2}\end{array}\right|=\frac{\mathrm{p}_{2}}{\mathrm{p}_{1}}$

$V$ an der Schroeff spreekt in dit verband van het punt van adequate substitutie. In dit punt is verdere substitutie niet meer lonend en wordt derhalve de optimale faktorkombinatie bereikt.

Voor de optimale faktorkombinatie geldt dus:

$$
\left|\begin{array}{c}
\mathrm{da}_{1} \\
\mathrm{da}_{2}
\end{array}\right|=\frac{\mathrm{p}_{2}}{\mathrm{p}_{1}} \quad \text { (formule 2) }
$$

of met gebruikmaking van formule 1 :

$$
\lambda_{1}=\frac{p_{1}}{p_{2}}
$$

De traditionele produktietheorie konkludeert dan ook dat de optimale faktorkombinatie van twee produktiefaktoren bijgegeven prijzen wordt bereikt

\footnotetext{
${ }^{7}$ ) Dat wil zeggen prijzen die onathankelijk zijn van de gevraagde kwantiteiten der produktiefaktoren.
} 
indien de marginale produkten van deze produktiefaktoren zich verhouden als hun prijzen.

Deze stelling kan uiteraard uitgebreid worden tot het geval van II samenwerkende produktiefaktoren mits ook voor deze faktoren geldt dat hun hoeveelheden kontinu veranderlijk en onderling substitueerbaar zijn.

In de traditionele produktietheorie wordt nu aangenomen dat de ondernemer voor elke produktie-omvang en bij elke prijsverhouding der produktiefaktoren steeds de optimale faktorkombinatie zal realiseren. Dit impliceert mede dat men er van uitgaat dat de ondernemer bij zijn streven naar verwezenlijking van de produktie tegen de laagste kosten geen enkele belemmering van sociale, juridische of financiële aard op zijn weg vindt.

\section{Isotime}

Het punt van adequate substitutie kan in een grafische voorstelling betrekking hebbend op twee produktiefaktoren worden uitgebeeld door middel van het raakpunt van de isoquant met de isotime. ${ }^{8}$ )

De isotime kan worden gedefinieerd als de meetkundige plaats van de punten die de faktorkombinaties van twee produktiefaktoren aangeven welke eenzelfde totaalkostenbedrag hebben.

In het geval de prijzen van de produktiefaktoren onafhankelijk zijn van de gevraagde kwantiteiten zijn de isotimen evenwijdige rechte lijnen welke met de ordinaat een hoek $\alpha$ vormen waarvan de tangens gelijk is aan de prijsverhouding van de produktiefaktoren.

Immers voor de isotime geldt:

$a_{1} \cdot p_{1}+a_{2} \cdot p_{2}=k$

$$
\mathrm{K}=\text { konstant kostenbedrag }
$$

In het snijpunt van $K$ met de ordinaat is:

$$
\begin{aligned}
\mathrm{a}_{2} \cdot \mathrm{p}_{2} & =\mathrm{K} \\
\mathrm{a}_{2} & =\frac{\mathrm{K}}{\mathrm{p}_{2}}
\end{aligned}
$$

In het snijpunt van $\mathrm{K}$ met de abcis is:

$$
\begin{aligned}
a_{1} \cdot p_{1} & =K \\
a_{1} & =\frac{K}{p_{1}}
\end{aligned}
$$

Dus is $\operatorname{tg} \alpha=\frac{a_{1}}{a_{2}}=\frac{P_{2}}{P_{1}}$

\footnotetext{
8) Men spreekt ook van iso-kostencurve.
} 
In grafiek 3 zijn een aantal isoquanten en isotimen getekend. Naarmate de isotimen verder van de oorsprong verwijderd zijn, stellen zij hogere kostenbedragen voor.

Grafiek 3

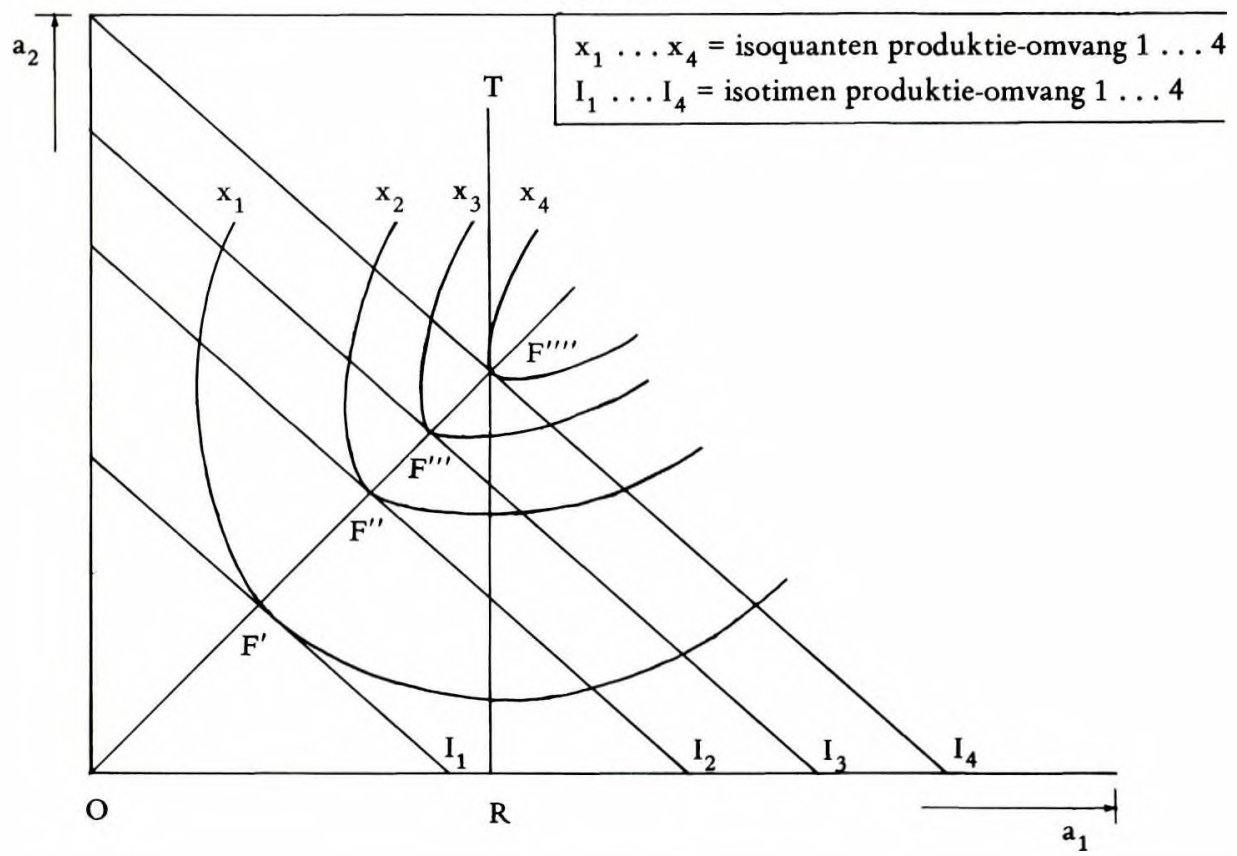

De optimale faktorkombinaties voor de verschillende hoeveelheden produkt kan men aflezen op de curve OF' $F^{\prime \prime}$.

Deze curve zouden wij willen betitelen als ,faktorcurve"." )

\section{Faktorcurve}

De in grafiek 3 getekende faktorcurve is een rechte door oorsprong. Dit betekent o.a. dat is uitgegaan van een bepaald verloop van de isoquanten en dus ook van de produktiefunktie. ${ }^{10}$ )

De isoquanten in grafiek 3 hebben namelijk als basis een homogeen lineaire produktiefunktie. Voor een dergelijke funktie geldt dat indien de hoeveelheden der samenwerkende produktiefaktoren met eenzelfde percentage worden veranderd ook de hoeveelheid produkt met datzelfde percentage en in dezelfde richting verandert. Derhalve is een produktiefunktie met twee samenwerkende produktiefaktoren lineair homogeen indien voor elke faktorkombinatie $\left(a_{1} ; a_{2}\right)$ geld $t$ :

$\mu \mathrm{x}=\mathrm{f}\left(\mu \mathrm{a}_{1} ; \mu \mathrm{a}_{2}\right) \quad \mu=$ percentage verandering

$\left.{ }^{9}\right)$ In de literatuur heeft deze curve verschillende benamingen.

Ragnar Frisch spreekt van ,expansion path" en van „,substitumal"

Erich Schneider duidt de curve aan als „Faktoranpassungscurve”.

Van der Schroeff spreekt van „,kostenlijn". Aldus wii hij duidelijk maken dat er een samenhang bestaat tussen de optimale faktorkombinaties en zijn normatieve kostenbegrip.

10) Benevens zijn de isotimen evenwijdige rechten. 
$\mathrm{Nu}$ is het in de literatuur over de produktietheorie gebruikelijk om van een homogeen lineaire produktiefunktie uit te gaan.

Dit zou gebeuren niet om principiële doch om praktische redenen.

Van der Schroeff spreekt van een ,vereenvoudiging" respektievelijk van een ,stylering ten opzichte van de werkelijkheid".

Frisch werkt een homogeen lineair en een niet-homogeen lineair verband wiskundig uit.

Schneider tekent de faktorcurve niet-lineair.

Rest ons te vermelden dat bij gegeven prijzen van de produktiemiddelen en een homogeen lineaire produktiefunktie de kosten van de optimale faktorkombinaties als funktie van de produktie-omvang een lineair stijgend verloop hebben.

Optimale faktorkombinatie bij prijzen van produktiefaktoren die afhankelijk zijn van de gevraagde kwantiteiten

Onder anderen Frisch en Schneider hebben de analyse van de optimale faktorkombinatie nog verfijnd door de prijzen van de produktiefaktoren niet als gegeven grootheden te beschouwen doch door ze afhankelijk te stellen van de gevraagde kwantiteiten van de produktiefaktoren

$\mathrm{p}_{1}=\mathrm{p}_{1}\left(\mathrm{a}_{1}\right)$ en $\mathrm{p}_{2}=\mathrm{p}_{2}\left(\mathrm{a}_{2}\right)$

Verondersteld wordt dat ook de prijsfunkties een kontinu verloop hebben. In het punt van adequate substitutie op de isoquant geldt dat de kostendaling als gevolg van de vermindering van $a_{1}$ met $\mathrm{da}_{1}$ gelijk is aan de kostenstijging als gevolg van de vermeerdering van $a_{2}$ met da $a_{2}$.

Derhalve moet: $d\left(a_{1} p_{1}\left(a_{1}\right)\right)=d\left(a_{2} p_{2}\left(a_{2}\right)\right)$

dus: $P_{1} d a_{1}+a_{1} \frac{d p_{1}}{d a_{1}} d a_{1}=p_{2} d a_{2}+a_{2} \frac{d p_{2}}{d a_{2}} d a_{2}$

$\mathrm{p}_{1}\left(1+\frac{\mathrm{a}_{1}}{\mathrm{p}_{1}} \frac{\mathrm{d} \mathrm{p}_{1}}{\mathrm{d \textrm {a } _ { 1 }}}\right) \mathrm{d} \mathrm{a}_{1}=\mathrm{p}_{2}\left(1+\frac{\mathrm{a}_{2}}{\mathrm{p}_{2}} \frac{\mathrm{d} \mathrm{p}_{2}}{\mathrm{d \textrm {a } _ { 2 }}}\right) \mathrm{d} \mathrm{a}_{2}$

De verhouding tussen de relatieve verandering in de prijs en de hoeveelheid van een produktiefaktor - prijselasticiteit genoemd - wordt aangegeven door $\epsilon$.
$\epsilon_{1}=\frac{\mathrm{a}_{1}}{\mathrm{p}_{1}} \frac{\mathrm{d} \mathrm{p}_{1}}{\mathrm{da}_{1}}$
$\epsilon_{2}=\frac{\mathrm{a}_{2}}{\mathrm{p}_{2}} \frac{\mathrm{dp_{2 }}}{\mathrm{d} \mathrm{a_{2 }}}$
$p_{1}\left(1+\epsilon_{1}\right) d a_{1}$
$p_{2}\left(1+\epsilon_{2}\right) d a_{2}$
$\frac{\mathrm{d} \mathrm{a}_{2}}{\mathrm{da}} \mid=$
$\frac{p_{1}\left(1+\epsilon_{1}\right)}{p_{2}\left(1+\epsilon_{2}\right)}$ 
Met gebruikmaking van formule 1 geldt dan:

$\frac{\lambda_{1}}{\lambda_{2}}=\frac{\mathrm{P}_{1}\left(1+\epsilon_{1}\right)}{\mathrm{P}_{2}\left(1+\epsilon_{2}\right)}$

(formule 4)

De traditionele produktietheorie konkludeert dan ook dat de optimale kombinatie van twee produktiefaktoren bij prijzen die afhankelijk zijn van de gevraagde kwantiteiten wordt bereikt indien de marginale produkten van deze produktiefaktoren zich verhouden als hun prijzen elk vermenigvuldigd met $(1+$ de prijsflexibiliteit).

Ook deze stelling kan uiteraard weer uitgebreid worden tot $\Pi$ samenwerkende faktoren mits ook voor deze faktoren geldt dat hun hoeveelheden kontinu variabel en onderling substitueerbaar zijn.

In het geval van afhankelijke prijzen zijn de isotimen krommen met een concaaf of convex verloop gezien vanuit de oorsprong. ${ }^{11}$ )

In geval van een homogeen lineaire produktiefunktie is de faktorcurve niet langer een rechte lijn doch een kromme.

\section{Korte termijn planning}

In de ekonomische literatuur wordt het instrumentarium van de traditionele produktietheorie vooral in verband gebracht met korte termijn-beslissingen. Dit is niet verwonderlijk omdat in de traditionele produktietheorie wordt uitgegaan van produktiefaktoren, respektievelijk voortgebrachte produkten van konstante kwaliteit.

Het aspekt van de technologische vernieuwing en de daaruit resulterende mogelijkheden van kwalitatieve veranderingen van produkt en produktiefaktoren blijven buiten beschouwing. Het ligt dan ook voor de hand dat de traditionele produktietheorie vooral van belang wordt geacht voor het analyseren van de mogelijke faktorkombinaties van de beschikbare soorten produktiefaktoren in een produktie-afdeling binnen het kader van de daar bestaande produktiecapaciteit die gewoonlijk wordt gemeten door middel van de capaciteit van het beschikbare (konstante) aantal machines. ${ }^{12}$ )

Zo maakt Schneider onderscheid tussen variabele produktiefaktoren en produktiefaktoren waarvan de hoeveelheid konstant blijft.

De variabele faktoren verdeelt hij in ,"limitationale faktoren" waarvan de hoeveelheden veranderlijk zijn en in een eenduidige relatie staan tot de produktie-omvang $(\mathrm{a} / \mathrm{x}=\mathrm{konstan} \mathrm{t})$ en in ,substitutionale faktoren" waarvan de hoeveelheden veranderlijk en substitueerbaar zijn. Hij past het instrumentarium van de traditionele theorie vervolgens toe op de ,,substitutionale faktoren".

Wet van de toe- en afnemende (fysieke) meeropbrengsten

Voornoemde wet is gebaseerd op de uitgangsstelling dat een konstante hoe-

11) Men raadplege Frisch, R. - Theory of Production.

12) Bij uitbreiding van de machinecapaciteit speelt namelijk veelal de keuze uit alternatieve produktietechnieken (kwalitatief verschillende produktiefaktoren) een rol.

$m a b \quad b l z .422$ 
veelheid van een produktiefaktor of een groep produktiefaktoren zich met verschillende hoeveelheden van een andere produktiefaktor (groep) laat kombineren met als resultaat het ontstaan van diverse produktieniveaus. Volgens deze wet zou de produktcurve, die weergeeft de produktie-omvang als funktie van de hoeveelheid van de variabele produktiefaktor(en), in eerste aanleg progressief, vervolgens degressief en ten slotte dalend gaan verlopen.

Uitgaande van gegeven prijzen van produktiefaktoren verlopen de kosten van de variabele produktiefaktoren als funktie van de produktie-omvang als het spiegelbeeld van de produktcurve. Dit betekent derhalve dat de variabele kosten eerst een degressief en vervolgens een progressief verloop hebben.

In verhandelingen over de traditionele produktietheorie wordt veelal de wet van de toe- en afnemende meeropbrengsten en het daaruit afgeleide verloop van de produktiekosten uitputtend behandeld. In eerste instantie lijkt dit vreemd omdat in een situatie waarin de wet van de toe- en afnemende meeropbrengsten optreedt de mogelijkheden van kwantitatieve substitutie wegvallen.

Indien van een produktiefaktor slechts een zekere hoeveelheid beschikbaar is dan zijn er met betrekking tot de aanwending van deze faktor twee situaties denkbaar:

Situatie 1: De aangewende hoeveelheid van de produktiefaktor kan al naargelang behoefte gevarieerd worden tot aan het niveau van de maximaal beschikbare hoeveelheid.

Situatie 2: De maximaal beschikbare hoeveelheid van de produktiefaktor wordt volledig aangewend onafhankelijk van het feit of de gewenste produktie-omvang hoog of laag is.

Situatie 1 leent zich - althans binnen zekere grenzen - voor de gebruikelijke benadering van de traditionele produktietheorie. In grafiek 3 is het lijnstuk RT getekend. De maximaal beschikbare hoeveelheid van $a_{1}$ is gelijk aan OR. Tot aan de produktie-omvang $x_{3}$ bestaan er mogelijkheden om minder van $a_{1}$ aan te wenden dan OR. Tot het niveau van laatstgenoemde produktieomvang bestaan er derhalve zekere mogelijkheden van kwantitatieve substitutie tussen $a_{1}$ en $a_{2}$. Bij een produktie-omvang $x_{i}$ waarvoor geldt $\mathrm{x}_{3} \leqslant \mathrm{x}_{\mathrm{i}}<\mathrm{x}_{4}$ zal de maximaal beschikbare hoeveelheid van $\mathrm{a}_{1}$ (OR) steeds volledig worden aangewend.

Een produktie-omvang $x_{i} \geqslant x_{4}$ kan niet meer verwezenlijkt worden.

Situatie 2 is het vertrekpunt voor de wet van de toe- en afnemende meeropbrengsten. $\mathrm{Nu}$ vervallen de substitutiemogelijkheden tussen $\mathrm{a}_{1}$ en $\mathrm{a}_{2}$ volledig omdat één van de twee produktiefaktoren konstant wordt gehouden. Daarom leent zich een dergelijke situatie in beginsel niet voor een toepassing van het instrumentarium van de traditionele produktietheorie.

De reden dat men toch situatie 2 in verband brengt met de traditionele produktietheorie is dat men wil analyseren in hoeverre bij de diverse produktie-niveaus de gekombineerde hoeveelheden der produktiefaktoren, respek- 
tievelijk de daarmee korresponderende kosten afwijken van de optimale faktorkombinaties, respektievelijk optimale kosten.

Het zou ons te ver voeren nader in te gaan op deze analyse. ${ }^{13}$ ). Volstaan wordt met op te merken dat de traditionele produktietheorie en de wet van de toe- en afnemende meeropbrengsten vertrekken van dezelfde principiële uitgangsbasis voor wat betreft de produktieverhoudingen, namelijk een produktiefunctie met variabele faktorverhoudingen. Dit zàl geen verwondering wekken aangezien het verschijnsel van de toe- en afnemende meeropbrengsten niet kan voorkomen in het geval de produktieverhoudingen zich kenmerken door een produktiefunctie met een vaste faktorverhouding. Toevoeging van een hoeveelheid van een variabele produktiefaktor aan een constante hoeveelheid van een andere produktiefaktor zou dan namelijk niet tot een produktievergroting leiden.

\section{OPVATTINGEN VAN ENIGE VOORAANSTAANDE BEDRIJFS- ECONOMEN}

Van der Schroeff H. J.

Deze onderzoeker heeft gewezen op enige irrealistische veronderstellingen van de traditionele produktietheorie.

a De traditionele theorie bedient zich van de assumptie dat de produktiefunctie continu is, hetgeen onbeperkte deelbaarheid van alle produktiefaktoren veronderstelt.

Van der Schroeff ${ }^{1}$ ) merkt op: „Bovenbedoelde vereenvoudigende veronderstelling verdraagt zich in genen dele met de praktijk van de produktie waarin de ondeelbare produktiemiddelen - daaraan kan geen twijfel bestaan onder invloed van de voortschrijdende techniek van mechanisering en automatisering een steeds grotere plaats innemen. Naar mijn oordeel kan men niet meer van een ,abstraherende" vereenvoudiging spreken, indien men de invloed van de ondeelbare middelen buiten beschouwing laat. Het probleem dat men dan gaat oplossen dreigt een schijnprobleem te worden."

Met gebruikmaking van de traditionele grafische voorstelling van isoquant en isotime laat Van der Schroeff de consequenties van de beperkte deelbaarheid van één van de twee samenwerkende produktiefaktoren zien.

De isoquant bevat dan een beperkt aantal realistische faktorkombinaties waarvan uiteraard die met de laagste kosten optimaal is.

Ook toont hij met behulp van grafische voorstellingen aan dat beperkte deelbaarheid het niet steeds mogelijk maakt de kwantitatieve verhoudingen van de produktiefaktoren aan te passen aan gewijzigde prijsverhoudingen hetgeen tot verstarring in de kwantitatieve verhoudingen leidt.

$b$ De traditionele theorie gaat er vanuit dat er voor het totale produktieproces een integrale produktiefunctie kan worden opgesteld.

13) Men raadplege Van der Schroeff.

14) blz. 260

$m a b$ blz. 424 
Wijzend op de complexiteit van het produktieproces merkt Van der Schroeff op dat dit in het merendeel van de gevallen niet mogelijk is. Hij is evenwel van mening dat de traditionele theorie nog mogelijkheden biedt voor het analyseren van deelprocessen bij de voortbrenging.

Ondanks voornoemde irrealistische uitgangspunten van de traditionele produktietheorie is Van der Schroeff van mening dat de theorie een „,denkpatroon" geeft dat bij uitstek geschikt is voor het inzicht in het vraagstuk van de kwantitatieve verhoudingen in de produktie.

Dit waarde-oordeel over de traditionele theorie vinden wij overdreven gunstig. Naar onze mening heeft de traditionele theorie voor de bedrijfseconoom een nogal beperkte betekenis. In feite is enkel de uitgangsstelling dat de produktie van een produkt in een zekere omvang door middel van verschillende faktorkombinaties zou kunnen geschieden van wezenlijk belang.

Immers de uitwerking van het keuzevraagstuk ter zake van de alternatieve faktorkombinaties gebeurt op grond van een hypothese die irrealistisch is, namelijk dat alle produktiefaktoren onbeperkt deelbaar zijn. Slechts op grond van deze hypothese mag de marginale analyse (differentiaalrekening) worden toegepast en wordt daarmede de theoreticus de mogelijkheid geboden algemene denkpatronen te ontwikkelen.

Voor de student in de bedrijfseconomie hebben deze denkpatronen ongetwijfeld didactische waarde maar zij mankeren vanwege het irrealistische uitgangspunt van de onbeperkte deelbaarheid instrumentele waarde.

Aangezien het in de bedrijfseconomie toch meer zou moeten gaan om praktisch toepasbare gedachtenconstructies moet daarom de betekenis van de traditionele theorie voor de bedrijfseconoom eerder als beperkt worden aangemerkt. Hetgeen wij als belangrijk zouden bestempelen is de conceptie van de produktiefunctie met variabele faktorverhoudingen.

\section{Gutenberg $\mathbf{E}$.}

De meest frontale aanval tegen de traditionele produktietheorie is ondernomen door Gutenberg die zover gaat het bestaan van produktiefuncties met variabele faktorverhoudingen en dus ook van kwantitatieve substitutiemogelijkheden in de industriële produktie te ontkennen.

Hij concentreert zijn kritiek op de wet van de toe- en afnemende meeropbrengsten. (uitgangsbasis: produktiefunctie met variabele faktorverhoudingen)

Volgens Gutenberg kan een vergroting van de produktie slechts geschieden indien de aangewende hoeveelheden van alle produktiefaktoren worden verhoogd. Hij licht deze opvatting toe met behulp van enige praktische voorbeelden.

\section{Voorbeeld:}

Een arbeider verwerkt op een zaagbank in vier arbeidsuren $100 \mathrm{~m}^{3}$ hout. Indien de verwerkte hoeveelheid hout moet worden verhoogd van 100 naar $100,1 \mathrm{~m}^{3}$ dan kan dit geschieden door een stijging van het prestatieniveau 
van zowel de arbeider als de machine. Stijging van het prestatieniveau van de machine veroorzaakt:

- additionele inzet van de machine, waardoor de technische slijtage toeneemt;

- additionele inzet van gereedschappen;

- additioneel energieverbruik, verbruik van smeermiddelen, etc.

Gutenberg concludeert dan dat de produktievermeerdering ontstaat door additionele „Leistungsabgaben" van alle produktiefaktoren.

Het blijkt dat hij het begrip ,hoeveelheid van een produktiefaktor" in de produktiefunctie definieert als de door deze faktor afgegeven prestatiehoeveelheid („Leistungsabgabe”). Nu heeft de traditionele produktietheorie dit begrip op een andere wijze gedefinieerd, althans terzake van apparatuur en menselijke arbeid. Zoals later zal worden aangetoond worden de hoeveelheden van deze faktoren uitgedrukt in aantallen. Welnu in voorgaand voorbeeld behoeven de aantallen niet te stijgen. De opvatting van Gutenberg is derhalve zeker geen absolute waarheid.

Wel zou men zich moeten afvragen of de door hem gehanteerde omschrijving van het begrip hoeveelheid van een produktiefaktor niet doelmatiger is. Voor een evaluatie vinden we bij Gutenberg echter geen aanknopingspunten aangezien hij niet concretiseert hoe hij de "Leistungsabgaben" van apparatuur en arbeid wenst te meten.

Een vanzelfsprekende maatstaf is de geleverde produktie. De produktiefunctie zou dan echter het karakter krijgen van een tautologie en dat brengt ons uiteraard geen stap verder. Een minder vanzelfsprekende oplossing met betrekking tot apparatuur, en naar onze mening de enige, zou meting door middel van de afschrijvings- en rentekosten kunnen zijn. De hoeveelheid apparatuur in de produktiefunctie zou dan evenwel worden uitgedrukt in financiële termen hetgeen het karakter van de produktiefunctie aantast. Bovendien gaat het - onder invloed van economische slijtage - lang niet altijd op dat bij verhoogde inzet van apparatuur de afschrijvings- en rentekosten stijgen.

Meting van arbeidsprestaties vanuit de ,input-kant” lijkt ons niet realiseerbaar. Men zou kunnen denken aan meting van de arbeidsinzet door middel van de werking van bepaalde lichaamsfuncties. Wij komen dan op het terrein van de fysiologie. Indien de fysiologie erin zou slagen algemeen geldende verbanden te vinden tussen de arbeidsinzet en de werking van bepaalde lichaamsfuncties ${ }^{15}$ ) dan resteert voor de econoom het vraagstuk een prijs toe te kennen aan de werking van de lichaamsfuncties.

Welnu, dit is niet mogelijk aangezien de prijs van menselijke arbeid niet wordt bepaald door zaken zoals bloeddruk en lichaamstemperatuur. Wij moeten dan ook concluderen dat het door Gutenberg gebruikte begrip "Leistungsabgabe" ondoelmatig is en dat zijn critiek op de Wet van de toeen afnemende meeropbrengsten (en daarmede op de produktiefunctie met variabele faktorverhoudingen) ongerechtvaardigd is.

15) Hetgeen vooralsnog niet mogelijk is gebleken.

$m a b$ blz. 426 


\section{Lassmann G.}

Bij de behandeling van de opvattingen van Gutenberg is reeds gebleken hoe belangrijk het is na te gaan op welke manier de elementen uit de produktiefunctie gedefinieerd moeten worden.

Het is teleurstellend te moeten ervaren dat de exponenten van de traditionele produktietheorie zich nauwelijks hebben verdiept in dit vraagstuk. Het is de verdienste van Lassmann dat hij dit probleem wel heeft aangepakt.

\section{Definitie van Produktiefunctie}

Lassmann komt tot de volgende conclusies:

a De produktiefunctie heeft betrekking op een bepaalde "Produktionsperiode", respektievelijk ,Produktionszeit".

Teneinde te komen tot een zinvolle relatie tussen de hoeveelheid produkt en de hoeveelheden produktiefaktoren moeten de hoeveelheden op eenzelfde kalenderperiode, de zogenaamde „Produktionsperiode” betrokken worden. Aangezien de produktie zich in het algemeen niet continu over de „Produktionsperiode" voltrekt doch onderbroken wordt door rusttijden moet ook de „Produktionszeit” in aanmerking worden genomen. Onder „Produktionszeit" wordt verstaan: „Die Zeit der effektiven Produktionstätigkeit”. ${ }^{16}$ )

In het geval van discontinue arbeid is de „Produktionsperiode” gelijk aan de „Produktionszeit" indien de eerste een zeer korte periode bestrijkt, namelijk de gebruikelijke dagelijkse werktijd (b.v. de 8-uren werkdag).

Aan de produktiefunctie zouden de volgende veronderstellingen ten grondslag moeten liggen:

- hoeveelheden produkt en produktiefaktoren hebben betrekking op een gelijke „Produktionsperiode"

- de "Produktionsperiode” is in steeds gelijkblijvende „Produktionszeiten” en rusttijden onderverdeeld. Bij volcontinue produktie zijn de „Produktionsperiode” en de „Produktionszeit” even lang.

$b$ Een produktiefunctie met variabele faktorverhoudingen is mogelijk indien de hoeveelheden van de "Potentialfaktoren" worden uitgedrukt in aantallen. ,Potentialfaktoren"1 7) zijn produktiefaktoren waarvan de prestaties per tijdseenheid (,Intensität”) gewijzigd kunnen worden. Onder deze faktoren kunnen voornamelijk menselijke arbeid en apparatuur worden gerangschikt. Kwantitatieve substitutie voltrekt zich in de vorm van een kombinatie van een „Intensitätsmässige Anpassung” van „Potentialfaktoren” en een „Quantitative Anpassung" van "Potentialfaktoren" en eventueel andere produktiefaktoren (grondstoffen, hulpstoffen, energie, etc.).

\section{Voorbeeld:}

Gegeven een zekere „Produktionsperiode”, respektievelijk „Produktionszeit” kan een bepaalde produktie-omvang van een produkt gerealiseerd worden door 10 machines en 5 arbeiders of door 12 machines en 4 arbeiders van

16) blz. 54

17) Term ontleend aan E. Gutenberg. 
dezelfde kwaliteit. Bij het laatste alternatief kan het aantal arbeiders worden verminderd (Quantitative Anpassung) door een stijging van de prestaties per arbeider („Intensitätsmāssige Anpassung”). Met betrekking tot de machines doet zich het omgekeerde voor.

\section{Instrumentele betekenis van Traditionele Theorie}

Lassmann verwerpt de traditionele theorie als instrument voor produktie- en kostenplanning. Het is evident dat de traditionele theorie met toepassing van de marginale analyse het werkelijk produktiegebeuren niet juist weergeeft. Evenals Van der Schroeff wijst ook Lassmann op de fictie dat alle produktiefaktoren onbeperkt deelbaar zijn en is ook hij van mening dat het niet in alle gevallen mogelijk zal zijn voor het totale produktieproces een integrale produktiefunctie op te stellen. Bovendien merkt hij op dat de traditionele theorie er geen rekening mee houdt, dat de ondernemer bij zijn streven naar de laagste produktiekosten belemmeringen van juridische, sociale en financiële aard op zijn weg vindt.

Dit alles behoeft echter niet te betekenen dat de produktiefunktie met variabele faktorverhoudingen als zodanig geen instrumentele betekenis kan hebben voor doeleinden van produktieplanning. Immers indien een produkt in een zekere produktie-omvang met behulp van meerdere faktorkombinaties kan worden geproduceerd dan bestaat er gewoonweg een produktiefunctie met variabele faktorverhoudingen en dan stelt zich het vraagstuk van de selectie van de faktorkombinatie met de laagste kosten.

Het blijkt nu dat Lassmann de produktiefunctie met variabele faktorverhoudingen verwerpt op grond van het uitgangspunt dat de kostenfunctie een éénwaardige functie moet zijn. Een éénwaardige kostenfunctie betekent dat voor elke produktie-omvang steeds unieke faktorhoeveelheden en faktorprijzen gelden.

Welnu, dit is met het oog op het praktische vraagstuk van de selectie uit de faktorkombinaties een onhoudbaar uitgangspunt en in dit kader dan ook verwerpelijk.

\section{Samenvatting en Conclusies}

De traditionele produktietheorie hanteert zekere uitgangspunten welke niet conform de werkelijkheid zijn. Daarom zijn de uitkomsten van de theorie irrealistisch. Voor de bedrijfseconoom is evenwel een bepaald element uit de theorie van wezenlijk belang namelijk de conceptie van de produktiefunctie met variabele faktorverhoudingen.

In de praktijk komt het namelijk voor dat een produkt in een zekere produktie-omvang door meerdere faktorkombinaties kan worden voortgebracht. Hier stelt zich derhalve het vraagstuk van de selectie uit de faktorkombinaties beschreven door middel van de produktiefunctie.

Van alle alternatieve faktorkombinaties zullen de kosten moeten worden bepaald waarna ten slotte de kombinatie met de laagste kosten preferabel is. Zoals is gebleken zijn wij het dan ook niet eens met Lassmann die aan de produktiefunctie met variabele faktorverhoudingen geen instrumentele waarde toekent. 


\section{ANALYSE VAN PRODUKTIEFUNCTIE}

In enkele opzichten kan de door Lassmann gemaakte analyse van de produktiefunctie ons geen bevrediging geven.

In de eerste plaats vinden wij zijn uiteenzettingen over de verschillende produktiefaktoren, in het bijzonder de „Potentialfaktoren", te oppervlakkig. Daardoor vermag hij niet duidelijk te maken dat er voor het totale fabricageproces geen integrale produktiefunctie kan worden opgesteld. Wij hebben bovendien bezwaar tegen het gebruik van de term „Potential” (in het Nederlands: ,potentieel”); een begrip dat in de fysika en de chemie wordt gebruikt ter aanduiding van verschillende hoeveelheden potentiële energie. Het meest gehanteerd wordt het begrip in de electriciteitsleer ter aanduiding van de hoeveelheid potentiële energie die de positieve eenheid van lading in een punt van een elektrisch veld ten opzichte van de aarde bezit. Ons ontgaat elk verband tussen het karakter van de verschijnselen in de fysika en de chemie aangeduid met behulp van het begrip potentiaal en het karakter van de produktiefaktoren arbeid en apparatuur.

In de tweede plaats maakt Lassmann niet duidelijk waarom hij de „Produktionszeit" gelijkstelt aan de officiële werktijden. De produktietijd moet gerelateerd worden aan de tijd dat de faktor arbeid of apparatuur (,,meetpunten") worden aangewend. Welnu dit betekent dat de produktietijd niet per se gelijk behoeft te zijn aan de officiële werktijd. Zoals wij zullen aantonen is deze keuze op doelmatigheidsgronden wel de juiste.

In het onderhavige deel III worden dan ook de volgende zaken behandeld: - de invloed van de structuur van het fabricageproces op het toepassingsgebied van de produktiefunctie.

- een nadere beschrijving van de inhoud van de produktiefunctie.

Bovendien wordt nog een samenvattend exposé gegeven van de diverse mogelijkheden van kwantitatieve substitutie, aangezien dit ons nuttig lijkt voor de bedrijfseconoom.

\section{De Structuur van het Fabricageproces}

Het eindprodukt van een fabricageproces ontstaat in het algemeen door een samenspel van veelsoortige apparatuur, veelsoortige arbeid en overige produktiefaktoren.

Men kan zich een dergelijk proces voorstellen als een reeks van deelaktiviteiten. Elke deelaktiviteit verricht zekere homogene prestaties welke nodig zijn om het eindprodukt voort te brengen. De prestaties van een deelaktiviteit worden gemeten met behulp van de voortbrenging op apparatuur of de voortbrenging door menselijke arbeid. Genoemde faktoren zijn derhalve meetpunten in het fabricageproces. De verschillende prestaties van de onderscheidene deelaktiviteiten moeten niet alleen aan bepaalde kwalitatieve eisen voldoen, maar behoren ook kwantitatief op elkaar te worden afgestemd. $\mathrm{Zij}$ laten zich echter gewoonlijk niet uitdrukken in termen van voortgebrachte eindprodukten. Dit is reeds het geval voor het fabricageproces in enge zin waar het finale produkt in feite ontstaat uit een samenspel van fabricageapparatuur annex machine-bedienend personeel en overige produktiefaktoren. 
Het geldt a fortiori voor het fabricageproces in ruime zin indien ook nog de zeer uiteenlopende prestaties van de fabricagehulpafdelingen in aanmerking worden genomen.

Daarom beschouwen wij het opstellen van één produktiefunctie voor het totale fabricageproces in feite als een onmogelijkheid. Het is wel mogelijk een produktiefunctie op te stellen voor een deelaktiviteit. Althans indien men een deelaktiviteit opvat als een verzameling van gelijke of nagenoeg gelijke prestaties. In het fabricageproces in enge zin kunnen de met behulp van een aantal identieke machines (apparatuur) verrichte gelijke of nagenoeg gelijke prestaties worden aangemerkt als een deelaktiviteit. In een voor deze deelaktiviteit op te stellen produktiefunctie wordt de produktie gemeten met behulp van de voortbrenging op de machines en zijn de produktiefaktoren de identieke machines en hun komplementaire middelen.

In beginsel kan ook een produktiefunctie worden opgesteld voor een deelaktiviteit welke geen gebruik maakt van apparatuur en waarvan de prestatiemeting geschiedt bij de faktor arbeid. Wij denken in dit verband vooral aan zekere kategorieën van dienstverlenende- en leidinggevende arbeid. Het komt ons voor dat dergelijke produktiefuncties veelal vaste faktorverhoudingen zouden hebben.

\section{Definitie Produktiefunctie}

a Ten einde tot een zinvolle relatie te komen tussen produktie-omvang en hoeveelheden produktiefaktoren zal de meting van beide betrokken moeten worden op dezelfde periode. In geval van een machinale deelaktiviteit zou men hiervoor de effektieve gebruikstijd, de produktieve gebruikstijd of de theoretisch maximale gebruikstijd van de machines over een zekere kalenderperiode kunnen nemen. De theoretisch maximale gebruikstijd is gelijk aan de officiële werktijden. De effektieve gebruikstijd is gelijk aan de theoretisch maximale gebruikstijd in aftrek van de uren dat de machine stilstaat. De produktieve gebruikstijd is de effektieve gebruikstijd minus de improduktieve machine-uren.

Indien de produktiefunctie betrokken zou worden op de produktieve gebruikstijd en de snelheid van de machine(s) zou konstant gehouden worden dan zou de produktiefunctie altijd het karakter hebben van een functie met vaste faktorverhouding. Immers kwantitatieve substitutie vereist ,Intensitätsmässige Anpassung" van de machine(s) en deze kan slechts gerealiseerd worden door verandering in de produktieve gebruikstijd of snelheid van de machine(s).

Maximale mogelijkheden van kwantitatieve substitutie ontstaan indien de mutaties in de produktieve gebruikstijden zich op zo'n ruim mogelijk vlak kunnen voltrekken. Welnu dit is mogelijk door het hanteren van de theoretisch maximale gebruikstijd. Daarom verdient het op doelmatigheidsgronden de voorkeur de produktiefunctie met variabele faktorverhoudingen te betrekken op een zekere dagelijkse, wekelijkse, maandelijkse, etc. produktietijd welke overeenkomt met de officiële werktijden.

b In de produktiefunctie worden de hoeveelheden arbeid en apparatuur uit-

$m a b$ blz. 430 
gedrukt in aantallen. De hoeveelheden van de overige faktoren (grondstoffen, hulpstoffen, etc.) worden uitgedrukt in de geëigende verbruiksmaten, zoals $\mathrm{kg}, \mathrm{m}, \mathrm{l}, \mathrm{kwh}$, etc.

c De identieke machines, de arbeiders waarvan dezelfde werkzaamheden en kundigheden worden verwacht en de diverse soorten overige produktiefaktoren behoren als afzonderlijke faktoren in de produktiefunctie te worden opgenomen.

Aggregatie van bepaalde produktiefaktoren zou enkel verantwoord zijn indien is gebleken dat de desbetreffende faktoren in alle alternatieve faktorkombinaties een konstante faktorverhouding vertonen. Vanuit een praktische gezichtshoek is aggregatie evenwel niet zinvol aangezien het voor de kostenbepaling nodig is de hoeveelheden per produktiefaktor te vermenigvuldigen met hun respektievelijke specifieke prijzen.

\section{Kwantitatieve Substitutie}

$\mathrm{Na}$ het toepassingsgebied van de produktiefunctie nader te hebben gekonkretiseerd en de elementen uit de produktiefunctie te hebben gedefinieerd gaan wij ons vervolgens bezig houden met het vraagstuk hoe dat kwantitatieve substitutie zich zou kunnen voltrekken met betrekking tot een machinale deelaktiviteit.

\section{Machines versus arbeiders}

Kan voor de realisatie van een deelaktiviteit in een bepaalde omvang het aantal machines worden verlaagd indien het aantal arbeiders wordt verhoogd, respektievelijk kan het omgekeerde worden bewerkstelligd?

Binnen het kader van een konstant gehouden werktijd kan het aantal benodigde machines in beginsel ${ }^{18}$ ) worden gewijzigd door een mutatie van de produktieve gebruikstijd of de snelheid van de machines.

- Een wijziging van de produktieve gebruikstijd kan mogelijkerwijs gerealiseerd worden door mutatie in het aantal machines dat door één arbeider of groep arbeiders wordt bediend.

Hier stelt zich derhalve het vraagstuk van de man/machinebezetting. ${ }^{19}$ ) - Wijziging van de machinesnelheid zou kunnen leiden tot een mutatie van het benodigd aantal machines. ${ }^{20}$ ) Een gelijktijdig optredende tegengesteld gerichte verandering in het aantal arbeiders kan slechts verwacht worden indien om technische redenen de prestaties per arbeider zich in tegengestelde richting ontwikkelen.

\section{Machines en arbeiders versus overige produktiefaktoren}

De aan te wenden hoeveelheden van de overige produktiefaktoren staan in het algemeen in een bepaald oorzakelijk verband met de aantallen machines en arbeiders en de wijze waarop deze laatste funktioneren.

18) Men zal in de praktijk rekening moeten houden met beperkte deelbaarheid van de produktiefaktoren arbeid en machines.

$\left.{ }^{19}\right)$ Een praktisch voorbeeld treft men aan bij Van der Schroeff.

20) Een hogere machinesnelheid kan resulteren in een hogere produktieuitval waardoor een daling van het aantal machines onmogelijk kan worden. 
Een duidelijk voorbeeld is de verbruikte energie door de machines. De verbruikte hoeveelheid energie is behalve van de technische eigenschappen van de machines afhankelijk van het aantal, de effektieve gebruikstijd en de snelheid van de machines. De hoeveelheden grondstoffen, halffabrikaten, hulpstoffen en gereedschappen zijn niet alleen afhankelijk van de machineparameters doch worden ook beinvloed door de handelingen van de mens. Onder andere de tussenkomst van de arbeider bij het instellen van de machine en het door hem al of niet efficiënt aanwenden van gereedschappen en materialen zijn belangrijke beinvloedingsfaktoren.

De rol van de arbeider is evenwel van subjektieve aard. Pogend stabiele relaties op te sporen tussen enerzijds de aan te wenden hoeveelheden grondstoffen, halffabrikaten, hulpstoffen en gereedschappen, en anderzijds de wijze waarop de aantallen machines en arbeiders funktioneren zullen we moeten trachten de rol van de arbeider enigszins te objektiveren. Dit zou kunnen geschieden door er van uit te gaan dat er in het fabricageproces, respektievelijk de deelaktiviteit een voldoende aantal bekwame arbeiders beschikbaar zijn om de gewenste zorg te besteden aan de apparatuur en de materialen. Met in achtneming van deze veronderstelling zijn de aan te wenden hoeveelheden grondstoffen, halffabrikaten, etc. afhankelijk van het aantal, de effektieve gebruikstijd en de snelheid van de machines. Nu laten zich ook enige vormen van substitutie tussen machines (annex bedienend personeel) en overige produktiefaktoren beschrijven.

- Een verhoging van de machinesnelheid zou enerzijds een daling van het benodigd aantal machines en anderzijds een stijging van het grondstoffen- en halffabrikatenverbruik (door hogere produktuitval) tot gevolg kunnen hebben.

Aldus ontstaat het keuzevraagstuk van minder machines maar meer grondstoffen en halffabrikaten of meer machines maar minder grondstoffen en halffabrikaten.

- Indien men bereid is de gewenste zorg voor gereedschappen en materialen op een lager niveau te brengen (dus extensievere aanwending) dan zou men de snelheid van de menselijke handelingen kunnen verhogen en aldus kunnen besparen op het aantal arbeiders en machines ten koste van het materiaalen/of gereedschappenverbruik. Opnieuw stelt zich hier het vraagstuk van de keuze uit diverse kombinaties van machines en arbeiders enerzijds en overige faktoren anderzijds. ${ }^{21}$ )

Opgemerkt zij dat de faktor huisvesting eigenlijk niet gerangschikt kan worden onder de ,overige produktiefaktoren”. De benodigde fabricageruimte is namelijk niet alleen afhankelijk van het aantal machines en arbeiders maar ook van de vereiste opslagruimte voor grondstoffen, halffabrikaten en gereed produkt.

Voorgaande analyse omtrent de kwantitatieve substitutiemogelijkheden tussen machines en arbeiders enerzijds en overige produktiefaktoren anderzijds heeft betrekking op deelaktiviteiten welke gebruik maken van machines

21) In het eerste geval is de machinesnelheid variabel. In dit geval is de snelheid van de menselijke handelingen variabel.

$m a b \quad b l z .432$ 
waarvan de snelheid een endogene faktor is die in het algemeen wordt gemeten door middel van de afgelegde afstanden van één of meer bewegende delen van de machine. Er zijn echter ook deelaktiviteiten welke apparatuur aanwenden waarvan de snelheid een exogene faktor is. Wij denken aan oven- en chemische processen waarvoor geldt dat de snelheid van de apparatuur een functie is van de hoeveelheden inputfaktoren (ingevoerde lucht, kolen, grondstoffen, etc.). De hoeveelheden van de overige produktiefaktoren staan in vaste verhouding tot de hoeveelheid produkt. Een wijziging in de faktorverhouding leidt tot een verandering van het produkt. Een dergelijke kwalitatieve wijziging vereist een nieuwe produktfunctie.

Door Frisch is een onderzoek verricht in de chocolade-industrie om de theoretische beschouwingen over kwantitatieve substitutie aan de praktijk te toetsen. Door toevoeging van cacaoboter aan de cacaomassa (gevormd uit geroosterde en gemalen cacaobonen vermengd met suiker) kon de viscositeit van de cacaomassa worden verlaagd waardoor de uitval van de (mislukte) chocoladerepen werd verminderd. Aldus kon de extra arbeid en het extra beslag op werktuigcapaciteit benodigd voor het omsmelten, opnieuw vormen en koelen van mislukte repen worden beperkt.

Het voorbeeld van Frisch met betrekking tot de chocolade-industrie is geen zuiver voorbeeld van kwantitatieve substitutie. Toevoeging van cacaoboter leidde tot een mutatie van de produktsamenstelling. Aangezien echter de produktwijziging van ondergeschikte betekenis was en de studie was gericht op het realiseren van kostenbesparingen door middel van andere kwantitatieve verhoudingen tussen de produktiefaktoren lijkt ons het onderzoek van Frisch als voorbeeld voor kwantitatieve substitutiemogelijkheden nog acceptabel.

Onze analyse over substitutie tussen enerzijds machines en anderzijds overige produktiefaktoren afsluitend mogen we derhalve bij wijze van aanvulling nog stellen dat substitutiemogelijkheden ook kunnen voorkomen in situaties dat de produktuitval word beinvloed door de hoeveelheid toegevoegde hulpstof.

\section{SAMENVATTING EN CONCLUSIES}

Het is onmogelijk een integrale produktiefunctie op te stellen voor het totale fabricageproces. Wel kan een produktiefunctie voor een deelaktiviteit worden opgemaakt. De elementen van deze functie moeten betrokken worden op een bepaalde produktietijd. Indien voor een zekere deelaktiviteit een produktiefunctie met variabele faktorverhoudingen kan worden opgesteld dan behoort de produktietijd gelijk te zijn aan de officiële werktijd. De hoeveelheden arbeid en kapitaal in deze functie worden uitgedrukt in aantallen en de hoeveelheden van de overige produktiefaktoren in de geëigende verbruiksmaten.

Door te wijzen op de diverse vormen van kwantitatieve substitutie tussen de produktiefaktoren van een machinale deelaktiviteit hebben wij getracht het vraagstuk van de optimale structurering van het produktieproces met praktische voorbeelden toe te lichten. 